\title{
[OSPODARKA NARODOWA
}

$11-12$

$(135-136)$

Rok XIII

listopad-grudzień

2002

Adam GLAPIŃSKI ${ }^{*}$

\section{Degeneracja instytucji kapitalistycznych \\ w teorii Josepha A. Schumpetera}

\section{Zmierzch przedsiębiorców}

Jedna z najbardziej wnikliwych dotąd przedstawionych instytucjonalnych analiz funkcjonowania gospodarki kapitalistycznej zawarta jest w pracach Josepha A. Schumpetera. Nie ulega przy tym wątpliwości, że w początkach XXI wieku zasadnicza czéść tej analizy jest nadal aktualna.

Właśnie rola instytucji w gospodarce jest centralnym tematem, wiążącym ze sobą logicznie wszystkie pięć części nieco chaotycznego i niekoherentnego zbioru esejów składających się na całość najsłynniejszej książki Josepha Schumpetera „Kapitalizm, socjalizm, demokracja” opublikowanej w 1942 roku.

Po przeprowadzeniu dowodu, że z punktu widzenia czysto ekonomicznego mechanizmu kapitalistycznego, kapitalizm jest nadal w pełni żywotny i co najmniej jeszcze w następnych pięćdziesięciu latach może generować wzrost dobrobytu wszystkich grup społecznych, Schumpeter przystępuje do analizy instytucji społecznych kapitalizmu i tam właśnie znajduje źródło jego potencjalnego, przyszłego upadku. Bowiem sama wyższość i doskonałość mechanizmu ekonomicznego czystej „maszyny kapitalistycznej” nie wystarczy, aby mógł on przetrwać. Podsumowując tę analizę Schumpeter stwierdza, że "nie mam zamiaru twierdzić na podstawie tych osiągnięć, że kapitalistyczne intermezzo ma szanse na długi żywot. W istocie rzeczy chcę (...) postawić dokładnie odwrotną tezę". Zresztą w sposobie upadku kapitalizmu, jak stwierdza, nie bẹdzie nic szczególnego, bowiem „większość cywilizacji zniknęła, zanim mogły one w pełni wykazać, w jakim stopniu spełniają swe obietnice" [Schumpeter, 1942, s. 160]. Jak mówi w jednym ze swych publicznych wykładów: „Ekonomiczne dokonania nie znaczą tak wiele dla ludzkości. Gdyby było inaczej, nie organizowano

Autor jest pracownikiem naukowym Szkoły Głównej Handlowej w Warszawie. 
by nigdy wypraw krzyżowych" [Schumpeter, 1991, s. 300]. Poza tym, osiągnięcia danego systemu i powszechny osąd tych osiągnięć w dobie masowych środków przekazu, to dwie zasadniczo różne sprawy. Fatum kapitalizmu jest zapisane nie w logice rozwoju jego bazy - używając za Schumpeterem języka Marksa - lecz w jego socjopsychologicznej nadbudowie.

I to właśnie "słabość oporu, jaki napotykało posuwanie się po socjalistycznej linii" w powojennej Anglii („nie tak reaguje silny naród na atak wymierzony w zasady, do których jest niezachwianie przywiązany"), umocniła - piszącego w 1949 roku w kolejnym wydaniu swej książki Schumpetera w przekonaniu, że te wydarzenia potwierdzają, że „etos kapitalizmu przeminął”. „I to właśnie - jak stwierdza - jest owo mane, tekel, fares" [Schumpeter, 1942, s. XXX].

Chcąc ukazać proces degeneracji ram instytucjonalnych społeczeństwa kapitalistycznego, Schumpeter przenosi analizę na tło rozważań z zakresu antropologii kulturowej i socjologii historycznej. Stwierdza, że po 50 tysiącach lat rozwoju społecznego, najprawdopodobniej pod wpływem konieczności ekonomicznej, ukształtowała się cywilizacja racjonalistyczna, której szczytowym jak dotąd tworem jest społeczeństwo kapitalistyczne. Rozumując w duchu słynnych analiz Webera i Sombarta, Schumpeter wskazuje, że „rachunek kosztów i zysków bẹdący pierwotnie wytworem ewolucji racjonalności ekonomicznej, (...) staje się potężną siłą napędową logiki przedsiębiorstwa. Z kolei ten typ logiki czy postawy albo metody, zdefiniowany w ten sposób i skwantyfikowany dla sektora ekonomicznego, rozpoczyna swój zwycięski pochód podporządkowując - racjonalizując - narzędzia i filozofię człowieka, jego praktykę medyczna, jego postrzeganie kosmosu, jego pogląd na życie, właściwie wszystko włącznie z jego pojęciami piękna i sprawiedliwości oraz ambicjami duchowymi" [Schumpeter, 1942, s. 152].

Rozwijając jakby dalej analizy Weberowskie, Schumpeter ukazuje, jak „duch racjonalistycznego indywidualizmu, duch wytwarzany przez powstający kapitalizm” stworzył „przestrzeń społeczną dla nowej klasy, która stawała w obronie indywidualnych osiągnięć na polu ekonomii" i przyciągnął do tej sfery „ludzi silnej woli i tẹgiej głowy". Tak jak w średniowieczu "główne drogi awansu i wielkich dochodów" dla emancypujących się jednostek wykazujących "talenty i ambicje wykraczające ponad normę" biegły poprzez kościół oraz dwory wielkich magnatów ziemskich i hierarchię dowódców wojskowych, tak w kapitalizmie i w społeczeństwie burżuazyjnym biegną one poprzez działalność gospodarczą zarówno w przemyśle, jak i w finansach ${ }^{1}$.

W rodzącym się kapitalizmie "sukces w roli przedsiębiorcy był (...) na tyle fascynujący dla wszystkich z wyjątkiem najwyższych warstw społeczeństwa feudalnego, by przyciągnąć wię̣kszość najtęższych głów i w ten sposób stać się podstawą dalszego sukcesu - by wytworzyć dodatkowe ciśnienie pary napę-

Jak to podsumowuje Hyman Minsky: „Przesłanie Schumpetera dla naszych czasów brzmi, że rynkowo zorientowany rozwój ekonomiczny potrzebuje dwóch analitycznie rozdzielnych rodzajów przedsiẹbiorców: innowatorów produktów i procesów oraz innowatorów finansowych". [Minsky H.P.: 1990, s. 72]. 
dzającej racjonalistyczną maszynerię. W tym sensie kapitalizm - a nie po prostu sama działalność gospodarcza - stał się poza wszystkim siłą napędową racjonalizacji ludzkiego postępowania" [Schumpeter, 1942, s. 154]. Tak więc to życie gospodarcze w społeczeństwie kapitalistycznym stało się główną sferą umożliwiającą awans społeczny, aż do szczebla klasy rządzącej, wszystkim ponadprzeciętnym jednostkom $i$ ich rodzinom. Jednostki obdarzone największą osobowością, siłą woli, energią, odwagą, kreatywnością i charyzmą w zracjonalizowanym na wskroś społeczeństwie burźuazyjnym przeistoczyły się w kapitalistycznych przedsiębiorców, których społeczną funkcją jest wprowadzanie innowacji. I to właśnie „ten rodzaj działalności jest głównym czynnikiem sprawczym powtarzających się fal prosperity, które rewolucjonizują organizm gospodarki, i nawracających recesji, wywołanych wpływem nowych produktów i metod, zakłócających dotychczasową równowagę" [Schumpeter, 1942, s. 162]. Tak skonstruowany jest właśnie, według Schumpetera, motor nieskażonej, nieskrępowanej „maszyny kapitalistycznej”.

Jednak, jak stwierdza pesymistycznie Schumpeter, łatwo można dostrzec, że w hipotetycznej sytuacji, w której zostaną spełnione wszelkie ludzkie potrzeby ekonomiczne i nastạpi stan nasycenia, funkcja przedsiębiorcy zaniknie. „Rezultatem tego będzie stan mniej lub bardziej stacjonarny. Kapitalizm, który z istoty jest procesem ewolucyjnym, ulegnie swoistej atrofii. Przedsiębiorcom nic już nie zostanie do zrobienia. Znajdą się w sytuacji bardzo przypominającej generałów w społeczeństwie, które na trwałe zapewniło sobie pokój. Zyski, a wraz z nimi również stopa procentowa, będą się zbliżać do zera. Nastąpi stopniowy zanik warstw burźuazji, utrzymujących się z zysków i z procentów. Zarządzanie przemysłem i handlem stanie się sprawą bieżącej administracji, a osoby trudniące się tym nabiorą w sposób nieunikniony cech biurokratów. Niemal automatycznie powoła się do życia socjalizm, bardzo trzeźwego typu. Zasoby ludzkiej energii bẹdą odpływać z działalności gospodarczej. Inne sprawy nie związane z gospodarką będą przyciągać umysły i zapewniać przygodę" [Schumpeter, 1942, s. 162].

Schumpeter podkreśla jednak, że taki stan nasycenia nie nastąpi w dającej się przewidzieć przyszłości, a co więcej, być może nie nastąpi nigdy. Jednakże związane z nim zjawiska pojawiają się stopniowo i częściowo już w trakcie rozwoju gospodarczego dązacego do nasycenia. I takie symptomy możemy wyraźnie już dziś obserwować. Bowiem „sam postęp można zmechanizować, podobnie jak zarządzanie gospodarką stacjonarną, i ta mechanizacja postępu może wywrzeć na przedsiębiorczość i na społeczeństwo kapitalistyczne wpływ porównywalny z ustaniem postępu gospodarczego" [Schumpeter, 1942, s. 162]. To już zaś doprowadzi do zaniku funkcji przedsiębiorcy oraz do załamania się społeczeństwa burźuazyjnego i porządku kapitalistycznego. Stanie się tak, gdyż funkcja przedsiębiorcy polega na rewolucjonizowaniu gospodarki, co wymaga od niego, by był jednostką ponadprzeciętną i umiejącą przeciwstawić się oporom środowiska.

Tymczasem, jak to dostrzega Schumpeter, we współczesnym świecie coraz łatwiej jest dokonywać nowych odkryć, robić rzeczy wybiegające poza doświad- 
czenie i tradycję, a "sama innowacja zostaje sprowadzona do rutyny" [Schumpeter, 1942, s. 163]. Co więcej „postęp techniczny w coraz większej mierze jest sprawą zespołów odpowiednio wyszkolonych specjalistów, którzy dają produkt, jakiego się od nich wymaga, i zapewniają jego funkcjonowanie w możliwy do przewidzenia sposób. Coraz szybciej zanika romantyka niegdysiejszych przygód handlowych, ponieważ wiele rzeczy, które kiedyś musiały się ukazać wynalazcy w przebłysku geniuszu, można dokładnie dzisiaj obliczyć" [Schumpeter, 1942, s. 163]. Społeczeństwo w takim świecie przyzwyczaja się do innowacji, nie stawia im oporu, lecz wręcz odwrotnie, przyjmuje je jako rzecz oczywistą i szczególnie chętnie nabywa nowe produkty i usługi. W ten sposób podstawowe cechy przedsiębiorcy - ponadprzeciętna osobowość, odwaga i siła woli - tracą na znaczeniu. Przedsiębiorca zostaje zastąpiony zautomatyzowanym, bezosobowym biurem i pracą zespołową. A „zracjonalizowana i wysoko wyspecjalizowana praca biurowa ostatecznie wymaże osobowość, a wykalkulowany wynik - wizję".

Schumpeterowska teoria zaniku przedsiębiorcy w dojrzałym kapitalizmie idzie drogą rozumowania Maxa Webera i Wernera Sombarta. Sombart, całkowicie podobnie do tego, jak czyni to później Schumpeter, opisuje zanik funkcji przedsiębiorcy (który także dla niego był motorem napędzającym kapitalistyczny system ekonomiczny) i ewolucyjne zastąpienie go przez urzędnika [Sombart, 1921-1927]. Również Max Weber wskazal, że postępujący, ewolucyjny proces standaryzacji, kartelizacji i zurzędniczenia powoduje tendencję „do coraz dalej idącej schematyzacji w prowadzeniu interesów. Tylko w najwyższej warstwie przedsiębiorców, ale i tutaj w coraz mniejszym stopniu, panuje jeszcze (...) stary, wolny, pionierski duch mieszczańskich przedsiębiorców z przeszłości. A zatem (...) coraz realniejsza staje się możliwość kierowania tą produkcją również wtedy, gdy nie ma się tych szczególnych cech, które ma przedsiębiorca i o których społeczeństwo mieszczańskie twierdzi, że są niezbędne dla prowadzenia interesów. Dotyczy to zwłaszcza karteli i trustów, gdzie miejsce pojedynczych przedsiębiorców zajął ogromny personel urzẹdniczy" [Weber, 1998, s. 161].

W odniesieniu do teorii zmierzchu kapitalistycznych przedsiębiorców, Schumpeter czyni analogię tych przedsiębiorców do klasy rycerskiej w średniowieczu. Indywidualne przymioty rycerskie, ich ponadprzeciętna zrẹczność i dzielność ukształtowały skład ówcześnie rządzącej klasy społecznej. Ponadprzeciętny sukces w zawodzie wojowania wynosił jednostki, ich rodziny i całą grupę społeczną do "trwałej pozycji społecznego przywództwa”. Chociaż wojny nie zanikły, to zmiany społeczne i techniczne ostatecznie, stopniowo zniszczyły całkowicie funkcję i pozycję klasy rycerskiej. Wojowanie stało się po prostu zawodem jak każdy inny, nie wymagającym ponadprzeciętnych cech i uzdolnień. Zupełnie tak samo jest, według Schumpetera, ze społeczną pozycją kapitalistycznego przedsiębiorcy. Jego społeczna rola związana do tej pory z pewną formą indywidualnego przywództwa, osobistej siły i odpowiedzialności za sukces traci na znaczeniu „zarówno wtedy gdy związane to jest $\mathrm{z}$ ustaniem potrzeb społecznych przez tę funkcję obsługiwanych, jak i wtedy, gdy potrzeby te są 
zaspokajane innymi, bardziej bezosobowymi metodami" [Schumpeter, 1942, s. 165].

Postępujący zanik funkcji przedsiębiorcy ma, w ujęciu Schumpetera, niezwykle znaczace dla społeczeństwa kapitalistycznego implikacje. Zjawisko to bowiem wpływa na pozycję całej klasy burźuazji. Zgodnie z teorią Schumpetera, przedsiębiorcy początkowo nie należą do burżuazji, ale przez swój sukces przebijają się ze swymi rodzinami do tej warstwy społecznej. Wejście do niej tak aktywnych i zdolnych jednostek wpływa na jej ciagłe wzmacnianie się. A więc zanik przedsiębiorców oznacza już na wstępie brak dopływu „świeżej krwi" dla całej klasy kapitalistów. Ale to nie koniec. Burżuazja składa się przede wszystkim z przemysłowców, kupców, bankierów, finansistów itp., którzy są ngdzieś po drodze pomiędzy przedsiębiorczością jako podejmowaniem ryzyka $^{2}$ i zwykłą bieżącą administracją sprawowaną na odziedziczonym obszarze". Według Schumpetera zyski, z których żyje warstwa burżuazji pochodzą właśnie z jej najbardziej aktywnego elementu, od przedsiębiorców. To przedsiębiorcy, wprowadzając innowacje osiągają zyski, a pozostali kapitaliści imitują ich działania, podążając jedynie wskazaną przez nich drogą (poprzez rozpoczęcie we własnym zakresie produkcji nowych towarów). Jak wskazuje Schumpeter, „w sensie ekonomicznym i socjologicznym, bezpośrednio i pośrednio, burżuazja zależy od przedsiębiorcy i jako klasa żyje i umiera wraz z nim, chociaż spokojnie można się liczyć z krótszym lub dłuższym okresem przejściowym, w którym nie bẹdzie ona w stanie ani żyć, ani umrzeć" [Schumpeter, 1942, s. 165].

Tak więc automatyzacja rozwoju w gospodarce kapitalistycznej prowadzi do zachwiania pozycji burźuazji przemysłowej. Zamiast utrzymywać się z zysków, pozostanie im jedynie płaca za bieżącą pracę administracyjną lub ewentualnie quasi-renta i zysk monopolowy (które mogą istnieć w stanie stacjonarnym). A zatem wielkie, doskonale zbiurokratyzowane koncerny ze swoimi laboratoriami i biurami badawczymi wprowadzającymi do gospodarki innowacje i automatyzującymi postęp, przyczyniają się do wyparcia z tegoż rynku małych i średnich firm, ale także wypierają przedsiębiorców, a tym samym niszczą burżuazję, pozbawiając ją jej funkcji i dochodów. Tak więc ostatecznie, jak konstatuje z ironią Schumpeter, „prawdziwymi dyrygentami socjalizmu nie byli intelektualiści czy agitatorzy, którzy go ogłosili, lecz Vanderbiltowie, Carnegie czy Rockefellerowie" [Schumpeter, 1942, s. 166].

2 Nie chodzi tu o ryzyko finansowe i tego sformułowania nie należy rozumieć jako odejścia Schumpetera od jego zasadniczego stanowiska, które rozwija w "Teorii rozwoju gospodarczego", że „przedsiębiorca nigdy nie jest tym, który ponosi ryzyko”. Ryzyko finansowe ponoszą, w ujẹciu Schumpetera, zawsze inni - kapitalista bankier udzielający pożyczki lub kapitalista właściciel firmy. Jeśli jest to ta sama osoba co przedsiębiorca, to tak czy inaczej, ryzyka finansowego nie ponosi ona jako przedsiebiorca, a jako kapitalista. Schumpeter zawsze krytykowal koncepcję przedsiębiorcy rozumianego jako „ponoszącego ryzyko", tak jak to znajdujemy np. w klasycznym ujẹciu u R. Cantillona lub F.A. Knighta. Por. szerzej na ten temat: [Schumpeter J.A., 1954, 5. 556]; [Kanbur S.M.,: 1991, s. 284-292]. 


\section{Zanik warstwy ochronnej}

Degeneracja kapitalizmu odbywa się również poprzez stopniową dekompozycję jego wielu innych instytucjonalnych struktur. Podobnie działo się w czasach, gdy umierał świat feudalny. Rodzący się wówczas kapitalizm zniszczył tradycyjny dwór i wieś (czy to poprzez stopniowe działania polityczne, czy poprzez rewolucję) oraz organizację cechową (również poprzez działania polityczne oraz skutki konkurencji ze strony przedsiębiorstw kapitalistycznych). Wraz z tymi przeobrażeniami nastąpiły zmiany w organizacji rządów, opinii publicznej, zanik politycznych i ekonomicznych przywilejów ziemiaństwa i szlachty. Ale, jak wskazuje Schumpeter, łamiąc przedkapitalistyczne ramy społeczne, kapitalizm nie tylko usuwał zmurszałe belki instytucjonalnej konstrukcji, lecz również „partnerów warstwy kapitalistycznej, z którymi symbioza była zasadniczym elementem kapitalistycznego schematu" [Schumpeter, 1942, s. 172]. Tym partnerem warstwy kapitalistycznej, ową warstwą ochronną, jak ją nazywa Schumpeter, była szlachta. Burżuazja bowiem jest nieprzygotowana do samodzielnego zajmowania się polityką wewnętrzną i zewnętrzną. „Bez osłony udzielonej przez jakąś grupę nieburżuazyjną, burżuazja jest politycznie bezradna i nie jest $\mathrm{w}$ stanie nie tylko przejąć narodowego przywództwa, ale nawet zatroszczyć się o swój partykularny interes klasowy. (...) Potrzebuje ona pana i mistrza" [Schumpeter, 1942, s. 171]. Dzieje się tak, bo jak uważa Schumpeter, klasa kapitalistów jest przyziemnie racjonalistyczna i ze swej natury niebohaterska, ponieważ prowadzenie zwykłej działalności gospodarczej właśnie takich cech od niej tylko wymaga.

Schumpeter dowodzi, że ukształtowana w młodym kapitalizmie klasa rządząca była „aktywną symbiozą dwóch warstw społecznych”: postfeudalnej arystokracji i kapitalistycznej burźuazji. Przy czym ta ostatnia udzielała pierwszej wsparcia ekonomicznego, uzyskując w zamian wsparcie polityczne. Schumpeter najwyraźniej zdaje się przywiązywać wielką wagę do udowodnienia tezy, że obecność przedstawicieli warstwy arystokratycznej w kapitalistycznych elitach rządzących (materialnie i duchowo) nie była tylko historycznym atawizmem, ale zasadniczym, konstytutywnym, i konstrukcyjnym elementem burżuazyjnego społeczeństwa (w literaturze „schumpeterologicznej” upowszechnione jest wiązanie tej tezy ustrojowej i szczególnego przywiązania do świata arystokracji Schumpetera z jego doświadczeniem źyciowym i sentymentalnym związkiem z rzeczywistością historyczną cesarsko-królewskich Austro-Węgier). Schumpeter posuwa się w swojej koncepcji aż do kategorycznego stwierdzenia, że harmonijne funkcjonowanie i przetrwanie nietkniętego $i$ żywotnego kapitalizmu uwarunkowane było jednoznacznie przetrwaniem u steru rządów elementu arystokratycznego. Najlepszym przykładem jest tu, według niego, Anglia. Bowiem właśnie tam element arystokratyczny szczególnie skutecznie „wchłaniał nieustannie umysły z innych warstw, które spływały ku polityce; stał sie reprezentantem interesów burżuazji i staczał bitwy w jej imieniu; musiał w końcu zrezygnować ze swoich ostatnich prawnych przywilejów; przy 
wszystkich tych ograniczeniach jednak i dla celów, które nie były juź jego własnymi, nadal zapewniał obsadę politycznej maszynerii, nadal kierował państwem, nadal rządził" [Schumpeter, 1942, s. 168-169].

Schumpeter stara się dowieść na przykładach historycznych, w szczególności francuskich i niemieckich, że tam gdzie burżuazja pozbyła się swego arystokratycznego partnera i całkowicie przejęła władzę polityczną, ponosiła niepowodzenia i nie była w stanie efektywnie i stabilnie rządzić. Jak stwierdza Schumpeter, przyczyna tego była oczywista. W przeciwieństwie do arystokracji, burżuazji brakowało „szczególnego nimbu” czyniącego z jego posiadacza władcę ludzi, „brakowało mistycznej chwały i pańskiej postawy”, „zdolności i nawyku przewodzenia i wymuszania posłuchu, które zapewniały prestiż u wszystkich klas społecznych". Przedstawiciele burżuazji wchodzący w skład kapitalistycznych elit politycznych nie są w żadnej mierze w stanie konkurować z dawnymi panami feudalnymi i rycerzami, którzy „z niezmierną łatwością i wdziękiem przedzierzgnęli się w dworzan, administratorów, dyplomatów, polityków i dowódców wojskowych takiego typu, który nie miał absolutnie nic wspólnego ze średniowiecznym rycerzem". Schumpeter, chciałoby się powiedzieć z arystokratyczną wyższością, stwierdza lekceważąco, że trudno by było powiedzieć, że współczesnego przemysłowca i kupca otacza jakaś mistyczna chwała, niezbędna przecież do trwałego rzadzenia ludźmi. Jak stwierdza ironicznie, „giełda jest kiepską namiastką Świętego Graala” [Schumpeter, 1942, s. 169].

Schumpeter posuwa się stopniowo do coraz bezwzględniejszego obnażania i podkreślania słabości przywódczych burżuazji i do udowadniania, że przywództwo ekonomiczne związane z prowadzeniem interesów, niełatwo rozszerza się na przewodzenie narodom. „Klasa burżuazji jest nieodpowiednio przygotowana do stawiania czoła problemom zarówno wewnętrznym, jak i międzynarodowym, które normalnie stają przed każdym ważniejszym krajem". Co więcej, burżuazja bez wsparcia ze strony dawnej arystokracji, jest politycznie bezradna i nie tylko nie jest w stanie przejąć skutecznie narodowego przywództwa, ale nawet dobrze chronić swój „partykularny interes klasowy”. Aby przetrwać skutecznie u władzy i kierować państwem, potrzebuje ona swego pana i mistrza.

Ewolucja kapitalizmu przywiodła burżuazję do prowadzenia takiej polityki, która zniszczyła tkankę społeczno-polityczną w o wiele większym stopniu niż to było potrzebne z punktu widzenia rozwoju. Polityka ta zniszczyła rzemieślników także tam, gdzie mogli trwać w nieskończoność. „Wmusiła też chłopu wszystkie błogosławieństwa wczesnego liberalizmu - wolne, nieosłonięte gospodarstwo i indywidualistyczny sznur, jakiego mu było trzeba po to, by się powiesić" [Schumpeter, 1942, s. 171]. Tak więc kapitalizm w swoim ślepym rozwoju połamał nie tylko postfeudalne bariery, które go krẹpowały, ale podciął też ważne przypory, na których się wspierał i zlikwidował postfeudalnych partnerów burżuazji, z którymi symbioza miała charakter organiczny.

Powyższe rozumowanie i argumenty doprowadzają Schumpetera aż do radykalnego stwierdzenia, że "mamy pełne prawo zastanawiać się, czy poprawne jest spojrzenie na kapitalizm jako sui generis formę społeczną, czy też 
w istocie rzeczy jest to tylko ostatnie stadium rozkładu feudalizmu" [Schumpeter, 1942, s. 172].

\section{Rozproszenie własnosci prywatnej}

Mechanizm kapitalistycznego rozwoju prze nieprzerwanie do przodu i po zburzeniu ram instytucjonalnych społeczeństwa feudalnego nie zatrzymał się i obecnie niszczy własną podstawę instytucjonalną. Dzieje się to także na płaszczyźnie konkurencji wielkich koncernów ze średnimi i małymi przedsiębiorstwami. Te ostatnie w tej walce nieuchronnie przegrywają i odchodzą w niebyt (tzn. przestają dominować w gospodarce i na rynku). Gospodarka się monopolizuje, a podstawową formą rynku monopolistycznego staje się oligopol. Razem ze średnimi i małymi przedsiębiorstwami w niebyt odchodzi też warstwa ich właścicieli wraz ze swymi rodzinami. Wywiera to nieodwracalne skutki nie tylko ekonomiczne, ale i w politycznej strukturze państwa, bo eliminowani są wyborcy, którzy w najbardziej konkretny sposób uosabiają podstawy własności prywatnej i swobody zawierania umów. Na placu boju pozostają wielkie zbiurokratyzowane koncerny. Koncernami zazwyczaj rządzą dyrektorzy, będący jedynie najemnymi urzędnikami. Własność natomiast jest rozproszona w rękach wielkich i małych akcjonariuszy. Dyrektorzy, według Schumpetera, nie utożsamiają się zazwyczaj z interesami właścicieli. Z kolei wielcy akcjonariusze są dalecy od postaw i funkcji charakterystycznych dla klasycznych, indywidualnych właścicieli, zaś drobni akcjonariusze - ciułacze często są nawet wrodzy swym korporacjom, a także nierzadko systemowi kapitalistycznemu jako takiemu.

Tak oto w kapitalizmie wielkiego biznesu zanika zjawisko jednoznacznej, „namacalnej" prywatnej własności środków produkcji, która stanowi jeden z fundamentów naprawdę prywatnej działalności gospodarczej ${ }^{3}$. (Podobnie degeneruje się instytucja swobody zawierania umów). „Własność zdematerializowana, wyzbyta swoich funkcji i »zaoczna nie wywiera wraźenia i nie wymaga moralnej dyscypliny, jakiej wymagała »bezpośrednia « forma własności. W końcu nie stanie już nikogo, kto troszczyłby się o nią - czy to w ramach wielkich koncernów, czy poza nimi" [Schumpeter, 1942, s. 175].

Warto przypomnieć, że Schumpeter już w „Teorii rozwoju gospodarczego" z 1911 roku „daje kreatywną i pełną wyobraźni analizę strategicznych aspektów innowacji i przedsiębiorczości w procesie transformacji od konkurencyjnego kapitalizmu do kapitalizmu wielkiego biznesu. Już tylko to dokonanie jak podkreśla Elliott - mogłoby zapewnić Schumpeterowi własną niszę w intelektualnej historii dwudziestego wieku" [Elliott, 1991, s. 353].

Jak pisze Aleksander Łukaszewicz, z dzisiejszego punktu widzenia „można oczywiście polemizować z Schumpeterem, czy ta wizja już siẹ zmaterializowała czy też proces jeszcze trwa, ale nie ulega wạtpliwości, że własność prywatna typu kapitalistycznego tak właśnie ewoluowała i tak nadal ewoluuje. Można by to określić mianem samoalienacji prywatnej wiasności kapitalistycznej" [Łukaszewicz, 2001, s. 57]. 
Natomiast w latach trzydziestych, Schumpeter już w pełni zdawał sobie sprawę z ustrojowej doniosłości procesu koncentracji kapitału we współczesnym mu kapitalizmie i towarzyszacych mu zjawisk oddzielenia własności od zarządzania i rozproszenia wiązki praw własności. Wraz z Berle, Meansem, Veblenem, i Burnhamem, antycypował główne tezy „kapitalizmu menedżerskiego", „rewolucji menedżerskiej” i późniejszej „teorii praw własności"4. (Schumpeter w swoich wystąpieniach powoływał się wprost na słynne badania struktury rynku Stanów Zjednoczonych przeprowadzone przez Gardnera Meansa w latach trzydziestych).

W książce napisanej w 1940, a opublikowanej w 1941 roku, James Burnham pisze: „W Stanach Zjednoczonych wielcy kapitaliści prywatni bardzo wyraźnie wycofują się z bezpośredniego kontaktu z wytwórczością, przechodząc od bezpośredniego zarządzania narzędziami wytwórczości do przypadkowych zebrań dyrekcji i do niemal całkowitej gospodarczej emerytury. Tym sposobem pozbywają się coraz bardziej władzy de facto nad narzędziami wytwórczości, na której ostatecznie opiera się kontrola społeczna. Ta ostatnia zarówno w przedsiębiorstwach prywatnych, jak i państwowych, przechodzi w ręce menedżerów" [Burnham, 1958, s. 258-259].

Koncepcje Schumpetera były także później punktem wyjścia dla Galbraitha i jego teorii technostruktury 5 .

\section{Antykapitalistyczna mentalnosć}

Dodatkowym, doniosłym zjawiskiem prowadzacym do destrukcji instytucjonalnych ram kapitalizmu jest wroga społeczna atmosfera, jaka się wokół niego wytwarza. Nieustający proces racjonalizacji życia we wszystkich jego przejawach, właściwy cywilizacji kapitalistycznej, doprowadza ostatecznie do wyprowadzonego $\mathrm{z}$ racjonalistycznych podstaw ataku na najważniejsze instytucje kapitalizmu i zasady moralne burżuazji. Ostatecznie dochodzi do sytuacji, kiedy „burżuj stwierdza ze zdumieniem, że racjonalistyczna postawa nie kończy się na tytułach królów i papieży, lecz również atakuje własność prywatną i cały system mieszczańskich wartości. Burźuazyjna forteca staje się wobec tego politycznie bezbronna" [Schumpeter, 1942, s. 176]. Burżuazja nie jest przygotowana do obrony i w „naiwnym oszołomieniu” oczekuje bezzasadnie, że racjonalne dowody przewag kapitalizmu będą dostatecznym argumentem obrony. Niestety, „zupełnie tak samo jak nikt nigdy nie żądał od królów, panów i papieży sądowych dowodów na potwierdzenie ich użyteczności, (...)

4 Por. [Veblen, 1932], [Burnham, 1941], [Berle i Means, 1967]. Obszerne omówienie tej problematyki znajduje się w: [Domańska, 1986].

5 Galbraith pisze, że przedsiẹbiorca zdefiniowany przez Schumpetera w „Kapitalizm, socjalizm, demokracja", będący ,jednostką zdolną do innowacji", zanika „w nowoczesnym przedsiębiorstwie przemyslowym (...) wraz z powstaniem nowoczesnej korporacji, wylonieniem się organizacji, jakiej wymagają nowoczesna technologia i planowanic, oraz rozdzieleniem funkcji posiadania kapitału od funkcji kontrolowania przedsiẹbiorstwa" [Galbraith, 1973, ss. 194-195]. 
tak rozprawa kapitalizmu toczy się teraz przed sędziami, którzy mają w swych tekach przygotowany wyrok śmierci" [Schumpeter, 1942, s. 178].

Argumenty w obronie kapitalizmu nie mają dostatecznej siły oddziaływania, bo efekty i zdobycze tego systemu stają się widoczne dopiero w długim okresie. W krótkim - dostrzegane są jedynie egoistyczny zysk i przypadki nieefektywności produkcji. Wywołuje to wrażenie, szczególnie u mas, że kapitalizm służy tylko klasie kapitalistów, żyjących z osiąganego zysku z produkcji. Co więcej, system ten nie jest w stanie stworzyć emocjonalnego przywiązania do burżuazyjnego porządku społecznego. W tej sytuacji ludzie wszelkie swe niepowodzenia zaczynają w mniejszym bądź większym stopniu przypisywać czynnikom zewnętrznym, a więc kapitalistycznej rzeczywistości. W końcu stały wzrost poziomu życia i czasu wolnego dodatkowo wzmacniają atmosferę wrogości, bowiem z psychologicznego punktu widzenia „ciągła poprawa uważana za coś zupełnie naturalnego i łączona $\mathrm{z}$ indywidualną niepewnością jest najlepszą receptą na wzrost społecznego niepokoju" [Schumpeter, 1942, s. 179].

Oczywiście, jak zauważa Schumpeter, masy nie są w stanie samodzielnie ukształtować swoich poglądów i ocen i przyjmują je z zewnątrz. Nie przekształcą też same swej postawy w skuteczne działania. Potrzebują zawsze nauczycieli z zewnątrz, mentorów, którzy je „uświadomią" i wskażą im cel ich dążeń. Schumpeter tẹ grupę mentorów określa mianem intelektualistów (jak mówi, określenie "grupa pismaków" jest chyba zbyt wąskie) i rozwija w związku z tym szerzej uwagi z zakresu "socjologii intelektualisty”. Jak podkreśla, „odmiennie niż każde inne społeczeństwo, kapitalizm nieuchronnie i mocą samej logiki swojej cywilizacji tworzy, kształci i utrzymuje grupy żywotnie zainteresowane społecznym niepokojem" [Schumpeter, 1942, s. 180].

Całkowicie analogiczną teorię społecznych źródeł opinii i nastrojów antykapitalistycznych rozwinął kolega Schumpetera z lat studenckich - Ludwig von Mises - w opublikowanej w 1956 roku „Mentalności Antykapitalistycznej” [Mises]. Podobny charakter mają też kąśliwe uwagi i komentarze Maxa Webera dotyczące negatywnej roli odgrywanej przez „zaślepionych literackich dyletantów, którzy są uzależnieni od przyspieszonej i stawiającej na aktualność produkcji książek"6.

Jak wskazuje Schumpeter, grupa intelektualistów nie stanowi typowej klasy społecznej, gdyż jej przedstawiciele wywodzą się z różnych warstw społecznych. Posiada jednakże swe charakterystyczne cechy. Jedną z nich jest np. wyższe wykształcenie. Każdy, kto je posiadł jest potencjalnym intelektualistą, i mało kto nim jest, jeśli go nie nabył. Z jednej strony podobne wykształcenie ułatwia wzajemne zrozumienie się, z drugiej jednak intelektualiści znaczną część swej działalności poświęcają „wzajemnemu zwalczaniu się i tworzeniu czołówki dla cudzych interesów klasowych" [Schumpeter, 1942, s. 180]. Ich siła tkwi w sło-

M. Weber, „Prawo wyborcze i demokracja w Niemczech", w: [Weber, s. 297]. Weber z satysfakcją odnotowuje np. wydarzenie, które „naszym głupim literatom pokazuje, że kapitalizm i sztuka nie muszą koniecznie trwać w owej naturalnej wrogości, jaką siẹ im przypisuje" [Weber, s. 281]. 
wie mówionym lub pisanym, a ich cechą specyficzną jest „brak bezpośredniej odpowiedzialności za sprawy praktyczne”, a zatem „brak bezpośredniej znajomości takich spraw, którą można posiąść tylko w praktycznym doświadczeniu" [Schumpeter, 1942, s. 181].

Grupy intelektualistów funkcjonowały już w czasach antycznych i w średniowieczu, ale były wówczas nieliczne i znajdowały się pod kontrolą władz świeckich i duchownych. „Typowemu intelektualiście wcale nie uśmiechała się perspektywa stosu, (...) grożącego heretykom. Z reguły znacznie bardziej odpowiadały mu zaszczyty i wygody" [Schumpeter, 1942, s. 182]. Intelektualista, jak pisze Schumpeter, dąży do osiągnięcia zaszczytów i profitów najczęściej przez „płaszczenie się i służalczość", ale czasami większe korzyści materialne przynosi słono opłacone powstrzymanie się od krytyki.

Wobec braku masowych środków przekazu informacji, aż do czasów kapitalistycznych intelektualiści nie stanowili wielkiego zagrożenia. Dopiero kapitalistyczny rozwój gospodarczy i burźuazyjna demokracja stworzyły im pole do popisu. Wraz z pojawieniem się prasy drukarskiej z jednej strony i z nastaniem wolności osobistej z drugiej, mogli swobodnie rozprzestrzeniać swe poglądy. „Tańsza książka, tańsza gazeta czy broszura, wraz z rozszerzeniem grona odbiorców (...) wraz z jednoczesnym wzrostem politycznego znaczenia anonimowej opinii publicznej - wszystkie te dobrodziejstwa, jak również coraz większa swoboda i niezależność od ograniczeń są ubocznymi produktami kapitalistycznej maszynerii" [Schumpeter, 1942, s. 183].

Jak trafnie wskazuje Lester C. Thurow w „Przyszłości kapitalizmu” dzisiaj „współczesnym odpowiednikiem Schumpeterowskiego pismaka jest telewizor. Oficjalnie wyśpiewuje on hymny pochwalne na cześć kapitalizmu, lecz nieoficjalnie wpaja zespół antyprodukcyjnych wartości. Dewizą jest bezpośrednia konsumpcja; nikt nie powinien odkładać natychmiastowego zaspokojenia na później" [Thurow, 1999, s. 411].

Swiat kapitalistyczny, jak podkreśla Schumpeter, sam tworzy, kształci i utrzymuje intelektualistów. Co więcej, w odróżnieniu od totalitarnych systemów socjalistycznego lub faszystowskiego, nie jest w stanie skutecznie kontrolować tej grupy, bowiem skuteczna kontrola sektora intelektualnego automatycznie oznaczałaby konieczność poddania się nieburźuazyjnym rządom i redukcji wolności osobistej burżuazji. W rezultacie nieuchronne jest utrzymanie przez burźuazję swobody dyskusji publicznej, w ramach której intelektualiści, zgodnie z logiką swojego funkcjonowania, będą „podgryzali podstawy społeczeństwa kapitalistycznego" i jego najważniejsze instytucje.

Podobnie konkluduje von Mises. Stwierdza, że „powstanie licznej klasy takich powierzchownych intelektualistów jest jednym z najmniej pożądanych zjawisk wieku nowoczesnego kapitalizmu. (...) Nikomu by nie zaszkodziło, aby coś zrobiono dla ukrócenia ich działalności, lub nawet całkowitego zlikwidowania ich klik. Jednakże wolność jest niepodzielna. (...) Zgnilizna moralna, rozpasanie i jałowość oraz społeczna szkodliwość większości tych, którzy tworzą klasę kandydatów na literatów i artystów, jest okupem jaki ludzkość musi płacić, aby pozwolić twórczym pionierom na dokonywanie wielkich dzieł" [Mises, 1991, s. 92]. 
Siła intelektualistów wzrasta nie tylko wraz z rozwojem masowych środków przekazu, spadkiem cen książek i prasy, ale również wraz z dynamicznym rozwojem oświaty, a zwłaszcza szkolnictwa wyższego. Rozwój tego rodzaju szkolnictwa przyczynia się do pojawienia się dwóch niekorzystnych zjawisk. Po pierwsze, wywołuje on nieuzasadniony ekonomicznie wzrost podaży specjalistów w zawodach nierobotniczych, a co za tym idzie wzrost bezrobocia wśród absolwentów wyższych uczelni lub niezadowalające warunki zatrudnienia dla tej grupy. Po drugie, powoduje pojawienie się osób trwale „niezatrudnialnych" (tzn. osób, które się nie nadają ani do pracy w charakterze pracownika umysłowego, ani robotnika). Te dwie grupy w sposób naturalny powiększają szeregi dogłębnie niezadowolonych intelektualistów. Jak wskazuje Schumpeter, jest to kolejny przykład, jak naturalny rozwój cywilizacji i gospodarki kapitalistycznej, upowszechniając dobrobyt, produkuje swoich zaciekłych wrogów.

Intelektualiści najlepiej realizują swoje antykapitalistyczne nastawienia, penetrując związki zawodowe powołane do życia przez rozwój kapitalizmu. Intelektualiści dostarczają tym związkom haseł i programów oraz radykalizują sposób ich działania. Aby zaskarbić sobie względy związkowców, muszą im „schlebiać, obiecywać, podburzać, muszą hołubić najprzeróżniejsze lewe skrzydła i nadąsane mniejszości, pełnić funkcję orędownika spraw wątpliwych" [Schumpeter, 1942, s. 190].

Działania i interesy grupy intelektualistów są jednym z ważnych elementów współtworzących atmosferę społeczną, „która wyjaśnia, dlaczego polityka staje siẹ coraz bardziej wroga kapitalistycznym interesom, tak silnie w końcu, że z zasady odrzuca wymagania maszyny kapitalistycznej, stając się poważnym hamulcem w jej funkcjonowaniu" [Schumpeter, 1942, s. 190-191].

Swe rozważania o intelektualistach Schumpeter podsumowuje: „rzadko kiedy występują w roli zawodowych polityków, jeszcze rzadziej zajmują w polityce odpowiedzialne stanowiska. Zaludniają oni jednak biura polityków, pisząc partyjne ulotki i przemówienia, odgrywając rolę sekretarzy i doradców, a także wyrabiają poszczególnym politykom dobrą opinię w prasie, co rzadko który polityk może lekceważyć. Spełniając te funkcje, wyciskają oni swe intelektualne piętno niemal na wszystkim, czego się dotkną" [Schumpeter, 1942, s. 191].

\section{Upadek mieszczańskiej rodziny}

Istnieje jeszcze jeden ważny, dodatkowy czynnik prowadzący do rozkładu kapitalizmu. Schumpeter dostrzega go wewnątrz samej warstwy burżuazyjnej. Jest to dezintegracja rodziny mieszczańskiej i wynikające z tego faktu reperkusje. Obserwacje i konkluzje Schumpetera na ten temat są podnoszone dzisiaj ponownie na przykład przez Edwarda Luttwaka w jego „Turbokapitalizmie"7.

7 Luttwak stwierdza, że „Homo Amerikanus jest genetycznie zaprogramowany, by służyć jako emocjonalne wsparcie całej rodziny (...), lecz dzisiaj zwykle żyje w stanie emocjonalnej samotności, do której ludzki gatunek jeszcze siẹ nie przystosowal" [Luttwak, 2000, s. 244]. 
Dezintegracja ta polega na postępującym spadku znaczenia życia rodzinnego i stanu rodzicielskiego oraz zmniejszania liczebności rodziny. Schumpeter już w latach trzydziestych dostrzegał coraz większą liczbę małżeństw z jednym dzieckiem lub bezdzietnych. Pierwotnie zjawisko to dało się obserwować tylko w warstwie kapitalistów i intelektualistów. Z czasem rozszerzyło się ono na całe społeczeństwo. Jak wskazuje Schumpeter, jest to naturalny wynik kapitalistycznej ewolucji racjonalizującej wszystkie sfery życia, w tym także sferę życia prywatnego. Posiadanie dzieci zaczęto rozważać w kategoriach indywidualnego rachunku korzyści i strat i wiązać z utratą komfortu. W ten sposób zasada utylitaryzmu wypiera tradycję. Co więcej, „kapitalistyczna wynalazczość dostarcza coraz skuteczniejszych środków antykoncepcyjnych, które przezwyciężają opór, na jaki w przeciwnym wypadku natrafiałby najpotężniejszy z ludzkich instynktów" [Schumpeter, 1942, s. 196].

Zmiana modelu życia rodzinnego i zmiana stylu życia powodują powstanie w sferze konsumpcji zjawiska analogicznego do przedstawionego wyżej „zaniku własności przemysłowej", które można określić procesem postępującego „zaniku własności konsumenta". Następuje zanik potrzeby posiadania tradycyjnego, mieszczańskiego domu rodzinnego. „Przeciętna rodzina o statusie mieszczańskim raczej zmniejsza trudności prowadzenia dużego domu i dużej wiejskiej rezydencji, wprowadzając $w$ ich miejsce małe i zmechanizowane domostwa korzystające w maksymalnym stopniu z zewnętrznej obsługi i przenoszące swe życie na zewnątrz - np. przyjmowanie gości w coraz większej mierze przenosi się do restauracji lub pubu" [Schumpeter, 1942, s. 196]. Co więcej, często dom rodzinny zastępowany jest przez mieszkanie w bloku mieszkalnym lub wynajęcie apartamentu w hotelu. W ten sposób kształtuje się nowy zracjonalizowany typ domostwa, odmienny styl życia. Styl ten pozwala na swobodę podróży, korzystanie z rozmaitych rozrywek, łatwość przemieszczania się.

Pociąga to za sobą poważne konsekwencje ekonomiczne. Dotąd bowiem, jak podkreśla Schumpeter, „typowo mieszczańska odmiana motywu zysku” miała swoje źródło w rodzinie i rodzinnym domu. Analizowany przez teorię ekonomii homo oeconomicus to oszczędzający i pracujący biznesmen zawierający w swej moralnej wizji żonę i dzieci. Motyw rodzinny wyznaczał cel funkcjonowania burżuazji, którym było przede wszystkim inwestowanie i akumulacja, a w mniejszym stopniu poziom bieżącej konsumpcji. Dezintegracja tradycyjnej rodziny mieszczańskiej skraca horyzont czasowy działania do jednego pokolenia. Rodzi się nowy homo oeconomicus, który ma już inne potrzeby, inne zmartwienia, działa odmiennie. "Zatraca on również kapitalistyczną etykę nakazującą pracę na rzecz przyszłości niezależnie od tego, czy się samemu bẹdzie miało szansę zebrać plon" [Schumpeter, 1942, s. 199]. Zatraca on skłonność do zarabiania, oszczędzania, inwestowania. W coraz większym stopniu nakierowany jest na bieżącą konsumpcję ${ }^{8}$. Przyjmuje postawę antyoszczędnościową i przyswaja sobie „an-

8 Lester C. Thurow stwierdzając, że Schumpeter „coraz bardziej wydaje sie mieć rację, gdy chodzi o rodzinę" pisze dalej: „w jaki sposób człowiek telewizyjny ma siẹ zmusić do dokonywania inwestycji i reform o zasadniczym znaczeniu dla przyszłości? Ani jego otwarta ideologia kapitalistyczna, ani jego ukryta ideologia telewizyjna nie uznaje poświẹceń dla budowania przyszłości" [Thurow, 1999, 55, 410-411]. 
tyoszczędnościowe teorie, które są przejawem filozofii krótkookresowej”. Zaczyna mieć odmienne spojrzenie na wartości i normy porządku kapitalistycznego. Coraz chętniej zaczyna słuchać sloganów wygłaszanych przez intelektualistów. Burżuazja wchłaniając te puste hasła, traci przy tym wiarę we własną religię.

\section{Transformacja rzeczy i ludzi}

Schumpeterowską analizę antykapitalistycznych tendencji w systemie kultury, polityki, przekazu informacji i stylu życia najbardziej spektakularnie podjął w latach siedemdziesiątych Daniel Bell. W książce „The Cultural Contradictions of Capitalism", Bell szeroko dowodzi, że we współczesnym kapitalizmie „zachodzi radykalny rozdział pomiędzy strukturą społeczną (systemem techno-ekonomicznym), a kulturą. Ta pierwsza jest rządzona przez ekonomiczną zasadę efektywności i funkcjonalnej racjonalności. (...) Druga jest rozrzutna, bezładna, wyrażająca nastroje antyracjonalne i antyintelektualne" [Bell, 1976, s. 37]. Bell powtarza jakby za Schumpeterem, że tradycyjne wartości burżuazyjne, takie jak samodyscyplina, oszczędność, cierpliwe odkładanie konsumpcji w czasie, wstrzemięźliwość wciąż jeszcze są obecne w systemie ekonomicznym, „ale ścierają się gwałtownie z kulturą, która te wartości burżuazyjne całkowicie odrzuciła. Stało się to częściowo, paradoksalnie, w wyniku logiki działania samego kapitalistycznego systemu ekonomicznego" [Bell, 1976, s. 37]. Oczywiście, jak wskazuje Bell nadal w zgodzie z rozumowaniem Schumpetera, fakt, że „kultura zaprzestała zajmować się motywacją do pracy i efektywności, a zaczęła się zamiast tego zajmować problemem, jak wydawać i używać" [Bell, 1976, s. 70] zmienia społeczny system motywacji i ma głẹbokie konsekwencje ekonomiczne.

Kilkanaście lat później, Michael Novak, zgadzając się z tym rozumowaniem, przyznaje, że to właśnie „tak odważni i apodyktyczni myśliciele społeczni, jak Joseph Schumpeter i Daniel Bell zauważyli, iż amerykański system moralno-kulturalny jest najsłabszym z trzech ogniw ekonomii politycznej, z których dwa pozostałe to demokratyczna republika i kapitalistyczna gospodarka" [Novak, 1993, s. 296]. Nowak podziela pogląd obu teoretyków, że zdrada wartości kapitalistycznych i burżuazyjnych przez elity intelektualne i duchowe ulokowane w kościołach, uniwersytetach, nauczaniu i prasie, „rozprzestrzenia się szybko za pośrednictwem kina, muzyki, magazynów i dzienników, a także innych włókien nerwowego systemu stanowiącego o życiu intelektualnym i duchowym narodu”. Jednocześnie stwierdza jednak, że „nie musimy traktować ich pesymizmu jako czynnika paraliżującego". Jeśli bowiem zło tkwi nie w systemie ekonomicznym i politycznym, a „w nas samych - a zwłaszcza w naszych moralnych, intelektualnych i kulturalnych elitach - mamy znakomitą okazję, by coś z tym zrobić”. Jest to w każdym razie szansa. „Nie gwarancja, lecz właśnie szansa" [Novak, 1993, s. 297]. Jak wiemy, taka jest właśnie emocjonalna intencja samego Schumpetera, który uważa, że antykapitalistyczne i antybur- 
żuazyjne nastroje, choć wynikają logicznie z procesu rozwoju kapitalistycznego ani nie są nieuchronne, ani nie muszą zwyciężyć, pod warunkiem jednak, że istnieje wola walki z nimi.

Tak więc, podsumowuje Schumpeter, to „w samym systemie kapitalistycznym tkwi tendencja do samozniszczenia". Kapitalistyczny proces ekonomiczny i niepowstrzymany pochód zwycięskiego racjonalizmu obniża znaczenie funkcji przedsiębiorców, eliminuje warstwy ochronne i partnerów burżuazji, tworzy atmosferę społecznej wrogości wobec kapitalizmu i likwiduje jego siły napędowe w postaci systemu motywacji. W pewnym sensie, zdaje się mówić Schumpeter, kapitalizm rozumiany jako proces nieustannych zmian, likwiduje sam siebie. Nie ma w tym właściwie nic dziwnego, bo jak twierdzi podsumowując swe analizy ewolucji kapitalizmu Schumpeter, „porządek kapitalistyczny nie tylko opiera się na podporach wykonanych z pozakapitalistycznego budulca, lecz również czerpie energię z pozakapitalistycznych wzorców zachowań, które jednocześnie musi wreszcie kiedyś zniszczyćn [Schumpeter, 1942, s. 200].

Schumpeter stwierdza, że proces kapitalistyczny, niszcząc ramy instytucjonalne cywilizacji kapitalistycznej, tworzy jednocześnie przesłanki cywilizacji socjalistycznej. Dlatego też właściwiej jest traktować dokonującą się ewolucję nie jako wyraz destrukcji porządku burźuazyjnego, ale jako transformację z jednego systemu do następnego. W procesie tej transformacji nie ma żadnej gwałtownej przerwy, czy przerywającej ciągłość luki, bowiem stopniowo, już w kapitalizmie „rzeczy i dusze zostają przekształcone w taki sposób, że w coraz większej mierze ulegają socjalistycznej formie bytowania".

Dla Schumpetera nie ulega wątpliwości, że proces transformacji może się dokonać płynnie (i trwać bardzo długo), bo podobnie jak Weber, traktuje kapitalizm i socjalizm jako różne formy funkcjonowania racjonalistycznego modelu życia, który jako taki może przejawiać się w nieskończenie rozmaitych historycznych egzemplifikacjach.

Teoria Schumpetera o postępującym zmierzchu kapitalizmu i jego transformacji w socjalizm jest nie tylko najgłośniejszym i najczęściej przytaczanym fragmentem jego dorobku teoretycznego, ale też fragmentem najbardziej błędnie interpretowanym i niezrozumiałym. Wynika to prawdopodobnie najczęściej z kontekstów ideologicznych. Natomiast w kontekście czysto analitycznym ma, jak moźna się domyślać, swoją przyczynę w wyrywaniu analizowanego fragmentu teorii Schumpetera z szerszego tła jego ogólnych koncepcji.

Dlatego też trzeba podkreślić wyraźnie, że z przedstawionej powyżej analizy poglądów Schumpetera, prezentowanych zarówno w „Kapitalizmie, socjalizmie, demokracji”, jak i we wszystkich innych wcześniejszych i późniejszych jego pracach, bynajmniej nie wynika, aby po pierwsze, przejście z kapitalizmu do socjalizmu było już za progiem. Przeciwnie, Schumpeter mówi zawsze o procesie, w którym sto lat jest krótkim okresem. Po drugie, z analizy prac Schumpetera nie wynika bynajmniej, aby to przejście mogło, czy miało się dokonać automatycznie. Przeciwnie, nawet jeśli będzie już możliwe, będzie ono ostatecznie przedmiotem wyboru politycznego. I wreszcie po trzecie, z analizy tej nie wynika w żadnym wypadku, aby Schumpeter mógł mieć na myśli jakikol- 
wiek inny socjalizm niż taki, który by przewyższał kapitalizm pod względem racjonalności ekonomicznej. To znaczy taki socjalizm, który równie dobrze można by określić np. wyższym stadium rozwoju kapitalizmu czy neokapitalizmem.

\section{Bibliografia}

Bell D., [1976], The Cultural Contradictions of Capitalism, Basic Books Inc. Publishers, New York.

Berle A.A. i Means G.C., [1967], The Modem Corporation and Private Property, Harcourt, Brace and World, New York.

Burnham J., [1941], The Managerial Revolution: What is Happening in the World, The John Day Publishers, New York, tłum. polskie Rewolucja manadzerska, Instytut Literacki, Paryż 1958.

Domańska E., [1986], Kapitalizm menedierski, Państwowe Wydawnictwo Ekonomiczne, Warszawa 1986.

Elliott J.E., [1991], Schumpeter's Theory of Economic Development and Social Change: Exposition and Assessment, [w:] Wood J.C. (red.), Joseph A. Schumpeter, Critical Assessments, Vol. IV, Routledge, New York 1991.

Galbraith J.K., [1967], The New Industrial State, The New American Library, New York, thum. za: J. K. Galbraith, Spoleczenistwo dobrobytu. Panistwo przemystowe, Państwowy Instytut Wydawniczy, Warszawa 1973.

Kanbur S.M., [1991], A Note on Risk Taking, Entrepreneurship, and Schumpeter, [w]: Wood J.C. (red.), Joseph A. Schumpeter, Critical Assessments, Vol. III, Routledge, New York.

Luttwak E., [2000], Turbokapitalizm. Zwyciezcy i przegrani swiatowej gospodarki, Wydawnictwo Dolnośląskie, Wrocław.

Łukaszewicz A., [2001], Dylematy ekonomiczne przelomu stuleci, Wydawnictwo Key Text, Warszawa.

Minsky H.P., [1990], Schumpeter, Finance and Evolution, [w]: Heertje A., Perlman M. (red.), Evolving Technology and Market Structure: Studies in Schumpeterian Economics, The University of Michigan Press, Ann Arbor.

Mises von L., [1991], Mentalność Antykapitalistyczna, Wydawnictwo Niepodległośc, Warszawa.

Novak M., [1993], Liberalizm - sprzymierzeniec czy wróg Kościoła. Nauczanie spoteczne Koscioła a instytucje liberalne, W drodze, Poznan.

Schumpeter J.A., [1942], Kapitalizm, socjalizm, demokracja, Wydawnictwo Naukowe PWN, Warszawa.

Schumpeter J.A., [1954], History of Economic Analysis, Oxford University Press, New York.

Schumpeter J.A., [1991], Can Capitalism Survive?, [w]: Schumpeter J.A., The Economics and Sociology of Capitalism, (pod. red. R. Swedberg), Princeton University Press, Princeton, New Jersey.

Sombart W., [1921-1927], Der modeme Kapitalismus, Duncker und Humblot, Berlin.

Thurow L.C., [1999], Przyszlość kapitalizmu. Jak dzisiejsze sity ekonomiczne kształtują siviat jutra, Wydawnictwo Dolnośląskie, Wrocław 1999.

Veblen I, [1932], The Theory of Business Enterprise (pierwsze wydanie 1904); The New American Library, New York.

Weber M., [1998], Socjalizm, [w:] M. Weber, Polityka jako zawód i powolanie, Spoleczny Instytut Znak, Kraków. 